The United Nations conference

on Technical Cooperation

between Developing Countries, which ended in Buenos Aires (right) last week, was a great success for third world countries, writes David Dickson

\author{
Sorry, for copyright \\ reasons some images \\ on this page may not \\ be available online
}

\title{
Developing countries to boost joint research
}

JOINT research projects between two or more developing countries are to receive greater emphasis, according to an ambitious 'plan of action' adopted last week by 138 member countries of the United Nations Development Programme. The plan was the main result of the conference on technical cooperation between developing countries (TCDC) which ended last week in Buenos Aires, Argentina.

The plan of action is based largely on suggestions made to the conference by the so-called 'Group of 77' - comprised now of 114 developing nations. The plan suggested that developing countries should "encourage existing national research and training centres to broaden their scope of activities to include programmes and projects which are of interest to several countries at a sub-regional, regional, and interregional level".

The conference also accepted a resolution submitted by Jamaica on behalf of the Group of 77 urging all developing countries to cooperate in strengthening existing research and training centres, with the intention of giving them "a multinational scope in the framework of TCDC" and where necessary establishing new institutions to achieve these ends.

And in order to prevent the plan of action being shelved as a well-meaning but ineffective document, the conference included in its recommendations specific directions for the way in which TCDC is to be encouraged and propagated, both within and outside the UN system.

Thus while rejecting as unnecessarily bureaucratic the idea of a new UN body with specific responsibilities for TCDC issues, the plan of action directs the UNDP to organise regular meetings-initially annual, subsequently biannual-or the planning ministers of member states to discuss progress towards TCDC goals.

Significantly the plan indicates that funds currently allocated by UNDP for regional use should now be devoted "to the maximum extent possible" to TCDC projects. Funds allocated to inter-regional or global projects could be used for TCDC projects proposed by two or more countries from different regions.

The significance of these decisions is that, while using international funds, the developing countries will be able to exert greater control over the way that money for technical projects is spent rather than the major impetus for the use of such funds coming from the developed countries.

Many delegates to the conference felt that the agreement on a regular meeting of planning ministers and the shift in the balance of control over technical projects had resulted in greater success for the conference than had previously been expected.

"The consensus that the conference was able to achieve on the plan of action represents a major victory for the developing countries", said $\mathrm{Mr}$ Abdel Razzak Meguid, Minister of Planning for Egypt and chairman of the main committee of the conference secretariat, in protest at the weakness of proposals put forward in an earlier draft of the plan.

"We have succeeded in making it acceptable to the North that it is in their interests to strengthen the 'horizontal' links between developing nations. That bridge is now not only accepted as a hope, but as a necessity if the world community is to survive".

However, few speakers at the conference pretended that TCDC was a new strategy. Background papers prepared for the conference, for example, described the complex network of overland trade routes that had existed between different countries in Africa before the arrival of European traders and colonialists.

Furthermore there has in recent years been a steady growth in joint research projects between various developing countries. The University of Chile, for example, is now co-ordinating a Latin American scheme for cooperation in postgraduate teaching and research in the biological sciences, which has already set up studies in areas such as the spread of plant viruses and the biological effects of working at high altitudes (such as in the mines of Peru).

What many delegates felt was new, however, was the emphasis that the conference was able to place on the concept of TCDC not merely as defined by a limited set of bilateral or multilateral agreements, but as a basic strategy for achieving the goals of what has come to be known as the 'new economic order' and the joint attempts of developing countries to counter the economic dominance of the developing world.

Thus initially the conference had been conceived in relatively narrow terms as dealing primarily with issues relating to technological co-operation, partly at the instigation of the more advanced of the developing nations, many of whom-such as the host country Argentina-are looking for new outlets for their goods and technical services.

However, during the evolution of the conference, the concept of TCDC has gradually become much broader, covering radical approaches to education and research, through to strengthening transportation, communication and information links among developing countries.

"Since agreeing in principle on the need for a "new economic order" in 1974 the United Nations has not done a single thing to translate a programme of action into an actionable programme. But I think that this conference has laid the framework for such an actionable programme", $\mathrm{Mr}$ Meguid said after the plan had been accepted by the conference.

Other delegates were similarly confident that the plan, which will now be placed before the General Assembly of the United Nations, provides a firm basis for a substantial shift in control over the content of development programmes from the developed to the developing nations, and that the regular meeting of planning ministers will provide considerable support for this trend.

As far as scientific research is concerned, the conference did not consider in detail any particular programmes or list of priorities, and many of the participants from specialised UN agencies such as the World Health Organisation and the Food and Agri- 
cultural Organisation had to remain primarily as observers-much to the frustration of some who claimed considerable practical experience in the issues under discussion.

However, the plan of action makes a number of suggestions about how research should be conceived within the TCDC framework. For example, it speaks of the need for developing countries to combine research efforts and share results "both with one another and with other developing countries by means of agreements on scientific and technological co-operation, strengthening national design, national laboratories, research centres and scientific and other institutions".

Putting flesh on these ideals will be one of the main objectives of next year's United Nations Conference on Science and Technology for Develop- ment, which will take place in Vienna. But many delegates left Buenos Aires with the feeling that despite internal differences, the developing countries have found in the issue of technical co-operation a way in which they can work together in presenting concrete demands to the developed world, and that this in itself was a major step in bringing the new economic order closer to reality.

\section{US geneticists look to Europe for research facilities}

Researchers at Genentech Inc, San Francisco, claimed at a Munich conference last week that they have induced bacteria to synthesise the two separate amino acid chains of human insulin-and to have combined these chains to make minute quantities of the hormone. Last year, the same team used a similar technique to induce bacteria to produce the hormone, somatostatin, and earlier this year, another team led by Walter Gilbert of Harvard University announced that they had persuaded bacteria to produce rat proinsulin attached to the bacterial ensyme penicillinase.

Synthesis of the artificial insulin gene used by Genentech began at City of Hope Medical Centre, California late last year. Researchers there synthesised artificial genes consisting of the DNA sequence corresponding to the amino acid sequence of the $A$ and $B$ strands of human insulin. Six months later, they turned the synthetic genes over to David Goeddel and Dennis Kleid, biochemists at Genentech.

Goeddel and Kleid inserted the synthetic genes for the two strands of insulin into plasmids which were then introduced separately into Escherichia coli. The bacteria replicated and expressed the genes as the $\mathrm{A}$ and $\mathrm{B}$ amino acid chains. These were then mixed to produce a fraction of a milligram of insulin which, it is claimed, is similar to human insulin.

Biological tests for the activity of insulin, however, have yet to be done. Even though chemical tests and radioimmunoassay have indicated the presence of the molecule, some researchers question the claim that the insulin produced is the chemical equivalent of human insulin. This is because radioimmunoassay cannot distinguish between different insulin varieties. Also, the B-peptide chains produced during the recent work are impure, and some researchers feel that the amino acid analyses conducted so far may be insufficient to establish the presence of the desired sequence.

The development of a new source of insulin for the treatment of diabetes has great practical importance. About $5 \%$ of diabetics are allergic to the animal insulin now used, and each patient requires 10 bovine pancreases per year at a cost of more than $\$ 100$. Bacterially produced insulin should eliminate allergic reactions and may be cheaper and easier to supply than animal insulin. Before the newly produced insulin could be marketed, however, it would have to undergo extensive animal and human tests which could take two to five years, though Genentech president Robert Swanson foresees no real difficulties in scaling up the procedure and passing the tests.

Such rapid success in developing a practical application of a technique raises a host of questions. The technique was discovered so recently that the original patent application has not yet been processed, and neither have revised safety regulations been implemented. Already the race for other commercial applications is hotly contested. New patents have been applied for, the breadth of the original patent remains unclear, and several leading American researchers are reportedly setting up shop in Europe to escape regulatory delays.

The original research leading to the procedure used in synthesising artificial genes was conducted with funds from the National Cancer Institute, the

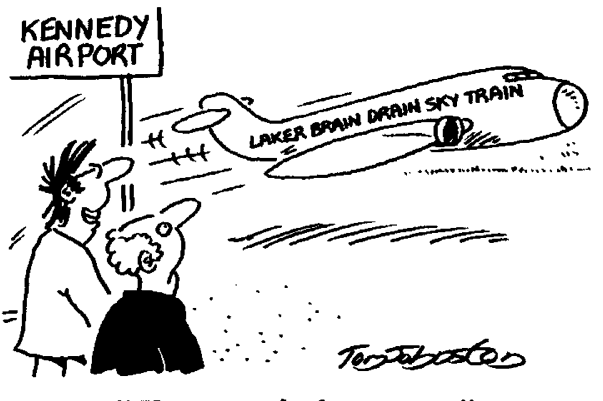

"Yes, we go both ways now"
National Science Foundation, the National Institutes of Health, the University of California and Stanford University. All parties eventually agreed that NIH would enter an institutional patent agreement with Stanford University and the University of California. Stanford would administer licensing of the technology, under terms of the agreement and share royalties equally with the University of California. After public hearings last spring, NIH granted Stanford permission to go ahead with licensing, provided any company granted a license would abide by NIH safety guidelines for genetic engineering.

Niels Reimers, Stanford's manager of technology licensing says he expects a patent to be issued within a matter of months, and believes it will cover much of the basic technique for producing recombinant DNA in $E$. coli. Stanford will probably wait until the patent is actually issued to begin licensing.

Such a patent would apply only in the United States. For that reason, and because of early stringent regulations, some scientists who are trying to create insulin by isolating and transferring a human gene have gone to Europe to work. Applications to use the country's first super-secure "P-4" facility, at Fort Dietrick, Maryland, will not be processed until later in the autumn. New, less stringent safety guidelines will also not go into effect until later this year.

William Rutter, a molecular biologist at the University of California, San Francisco, is already looking to Europe as the place to continue his work on the human gene for insulin. "One is forced to do that if one wants to do the experiments" he says. His group is planning to work in France. The potential advantage of using the natural gene for insulin, he says, is that it includes additional information for folding and joining the $A$ and $B$ peptide strands.

John Douglas 